\title{
Evaluation the effect of local yeast and imported yeast as supplementary food on the African catfish (Clarias gariepinus) in Egypt
}

\begin{abstract}
This study aims to evaluate the effect of different graded levels of local and imported yeast (Saccharomyces cerevisiae) on the growth performance of African catfish, Clarias gariepinus. 250 fingerlings of the African catfish were collected from Edku Lake (northern Egypt) to carry out an experimental study. After a two-week acclimation period, the fish were divided into 5 groups of 50 fish each. Then, each group of fish was randomly distributed into aerated rectangular fiber glass tanks $(0.90 \times 3.70 \times 1.90 \mathrm{~m})$. The tanks were filled with tap water in which oxygen saturation was $5.6 \mathrm{~g} / 1$ at $\mathrm{pH} 7.9$; water temperature range from 26 to $27^{\circ} \mathrm{C}$; and, photoperiod was 12:12 Light: Dark. The results showed that the supplementation of local yeast, Saccharomyces cerevisiae, improved growth and feed utilization. Significant results were recorded for treatment group 2 (G2) that fed on commercial pellets diet with $2 \%$ local Baker Yeast compared to the control group. It was shown that the yeast supplementation significantly affected the whole-fish body composition (Feed intake-dry matter, protein intake and energy intake). All treatments exhibited higher values compared to the control group. It was suggested that the positive effect of live yeast in African catfish diets under the present study conditions may be due the release of growth factors at the selected yeast concentration. In this study treatment of G2 that fed on commercial pellets diet with $2 \%$ local Baker Yeast showed the lowest values for dray matter, ether extract and ash content, while it showed highest value for crude protein compared to the control group. Hematological analysis of all the treatment groups showed satisfactory values compared to the control groups. From the economic point of view similar to the imported yeast, the use of cheap local baker's yeast for African catfish also increases their growth and production under farming conditions.
\end{abstract}

Keywords: Saccharomyces cerevisiae, pH, Clarias gariepinus, Fish, Growth, Significant, Baker's yeast
Volume 2 Issue 3 - 2015

\author{
Mohamed M M El-feky, ${ }^{2}$ Mohamed H Mona,' \\ Ensaf E Elgayar,' Abeer A Alm-Eldeen,' \\ Ahmed M Heneish ${ }^{2}$ \\ 'Department of Zoology, Tanta University, Egypt \\ ${ }^{2}$ National Institute of Oceanography and Fisheries, Egypt
}

Correspondence: Mohamed M M El-feky, Marine Biology, National Institute of Oceanography and Fisheries (NIOF), Alexandria, Egypt, Email dive_mmae2010@yahoo.com

Received: May 06, 2015 | Published: June II, 2015
Abbreviations: ADG, Average Daily Gain; FCR, Feed Conversion Ratio; HIS, Hepatosomatic Index; GSI, Gonadosomatic Index; ALT, Alanine Aminotransferase; AST, Aspartate Aminotransferase; RBC, Red Blood Cells; WBC, White Blood Cells; ANOVA, Analysis Of Variance; TP, Total Protein; BSA, Bovine Serum Albumin

\section{Introduction}

Many investigations have been carried out on the African catfish Clarias gariepinus in different African countries; but in Egypt, there are few studies on this species. So this study is carried out to provide more information about this species in Egypt. Aquaculture production is one of the most important activities/means that can participate to solve a world feeding problems. It becomes a worldwide practice and has been for years. ${ }^{1}$ Aquaculture in Africa is a relatively new industry and is not practiced on a wide scale. Fish pond culture in sub-Saharan Africa started in Kenya in 1924 and later spread to other parts of the continent. ${ }^{2}$ The African catfish, Clarias gariepinus (Order: Siluriformes, Family: Clariidae), is a freshwater eurytopic species. The superior performance of this species compared to other Clarias species in terms of growth rate has probably contributed to fact that Clarias gariepinus has been widely introduced to areas outside its natural range. ${ }^{3}$ Introduction Probiotics are usually defined as live a microbial feed supplement which beneficially affects the host animal by improving its intestinal microbial balance. ${ }^{4}$
Baker's yeast, Saccharomyces cerevisiae, is used for the bakers industry that contains various immunostimulating compounds such as $\beta$-glucans, nucleic acids as well as mannan oligosaccharides and it has the capability to enhance immune responses ${ }^{5}$ as well as growth ${ }^{6}$ of various fish species. Despite the existing controversy, carbohydrate levels in Clarias gariepinus diets are often substantial and reportedly range from 15 to $35 \% .^{7}$ The intensive use of antibiotics to prevent and control bacterial diseases in aquaculture has led to an increase in antibiotic-resistant bacteria. ${ }^{8}$ These processes are the main functions of the digestive system which is one of the organ systems that has been studied histologically in African catfish. ${ }^{9}$ Thomas et al. ${ }^{10}$ Clarias batrachus is a species of catfish of the family Claridae, Pathogenicity of Aeromonas salmonicida was studied in healthy fish. In recent years, the role of probiotics in nutrition and health of certain aquaculture species have been investigated. ${ }^{11-13}$ The main objective of the present study was to evaluate the effects of different graded level of local and import yeast (Saccharomyces cerevisiae) as a probiotic on African catfish, Clarias gariepinus, concerning their growth and production performance, feed utilization as well as hematological parameters.

\section{Materials and methods}

\section{Fish culture and feeding regime}

250 Fingerlings of the African catfish Clarias gariepnus (mean body weight $100 \pm 0.67 \mathrm{~g}$ ) were collected from Edku Lake then transported to the fish hatchery in El-Max Fish farm, National 
Institute of Oceanography and Fishers (NIOF), Alexandria, Egypt. After two weeks for acclimation, the fish were divided into 5 groups, 50 fish each. Consequently, the fish were randomly distributed to 25 fish per cubic meter of rectangular fiber glass tanks and kept in aerated rectangle fiber glass tanks $(0.90 \times 3.70 \times 1.90 \mathrm{~m})$ (Figure 1$)$. The tanks were filled with tap water in which oxygen saturation is $5.6 \mathrm{~g} / \mathrm{l}$ at $\mathrm{pH}$ 7.9. Water temperature range was $26-27^{\circ} \mathrm{C}$. Photoperiod $12: 12$ Light: Dark). The five fish groups were exposed to different five diets; group 1 (G1) that fed on commercial pellets diet without yeast and acts as a control, group $2(\mathrm{G} 2)$ that fed on commercial pellets diet with $2 \%$ local Baker Yeast (Saccharomyces cerevisiae), group 3 (G3) that fed on commercial pellets diet with $4 \%$ local Baker Yeast (Saccharomyces cerevisiae), group $4(\mathrm{G} 4)$ that fed on commercial pellets diet with $2 \%$ imported Tonilisite (Saccharomyces cerevisiae) and group 5 (G5) which fed on commercial pellets diet with $4 \%$ imported Tonilisite (Saccharomyces cerevisiae). The feeding rate was 3\% of the biomass twice a day, at $10.00 \mathrm{AM}$ and $2.00 \mathrm{PM}$, for six days a week for a period of 8 weeks. The composition and chemical analysis of the experimental pellets were measured and presented in Tables $1 \& 2$. The diets were analyzed according to the standard methods of AOAC (1990). The experimental tanks were inspected daily to remove dead fish, if present.

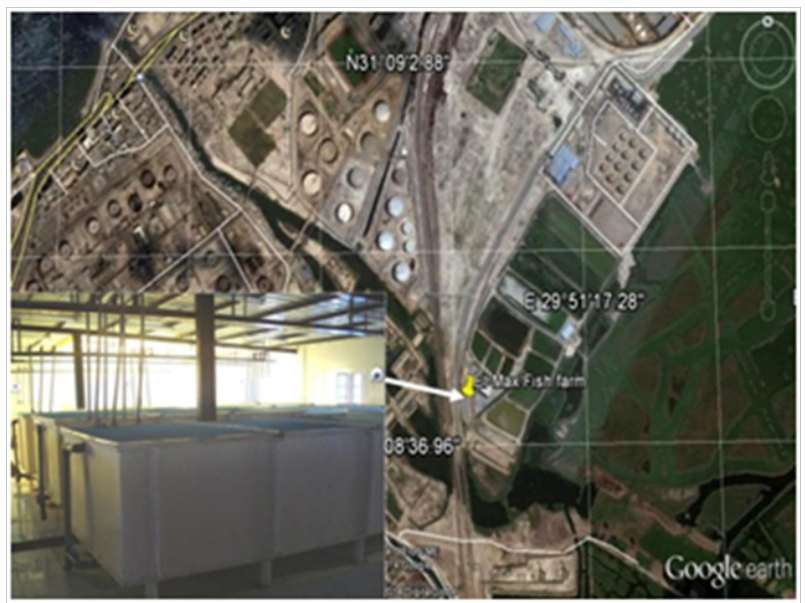

Figure I Fiber glass tanks.

\section{Chemical analysis of fish and diets}

The whole-fish body and the tested diets were analyzed according to the standard methods of AOAC (1990) for moisture, crude protein, crude fat and ash. Moisture content was calculated by determining the differences before and after drying oven at $105^{\circ} \mathrm{C}$ for 16 hours. Nitrogen content was determined by the micro-Kjeldahl method. A factor of 6.25 was used to convert the nitrogen content to the crude protein. Crude fat was determined by drying the samples at $100^{\circ} \mathrm{C}$ for 12 hours and then extracting the crud fat with petroleum ether in soxhlet extractor for 4 hours. Total ash was determined using muffle furnace at $550^{\circ} \mathrm{C}$ for $6 \mathrm{~h}$ (Table 1$)$.

Water samples were collected twice per week from each aquarium. Temperatures were measured on site with YSI model. The salinity was measured by using Salino-meter. Unionized ammonia was measured using Drel/2 Hach kits. The $\mathrm{pH}$ was measured using a $\mathrm{pH}$-meter. All the water quality parameters were within the acceptable ranges for the fish growth ${ }^{14}$ (Table2).

Weight gain, Average daily gain (ADG), Percentage average daily gain (ADG \%), Specific growth rate (SGR \%) and Survival rate(S \%) was calculated according to the following equation: Gain $(\mathrm{Gg})=$ final fish weight $(\mathrm{g})$ - initial fish weight $(\mathrm{g})$. Gain $\%(\mathrm{G} \%)=$ Gain of fish (g) / initial weight of fish (g) X 100. ADG = Gain (g) / time (DAY). $\mathrm{ADG} \%=\{\mathrm{ADG} /$ Initial weight of fish $(\mathrm{g})\} \mathrm{X} 100 . \mathrm{SGR} \%=100 \mathrm{X}$ $\{(\mathrm{In} W 2-\mathrm{In} \mathrm{W} 1) / \mathrm{T}\}$ Where........... W2 is the final weight of fish (g). Where........... W1 is the initial weight of fish $(\mathrm{g})$. In is natural log. T is the time (day). Survival rate(S \%) was determinate as follows: $\mathrm{S} \%=$ Number of fish at the end $\div$ Total initial number of fish $\mathrm{x} 100$.

Table I Percentage composition (\%) of the experimental diet

\begin{tabular}{llllll}
\hline Ingredients & G & G2 & G3 & G4 & G5 \\
\hline Fish Meal & 15 & 15 & 15 & 15 & 15 \\
Soy Bean & 25 & 25 & 25 & 25 & 25 \\
Yellow Corn & 20 & 20 & 20 & 20 & 20 \\
Rice Brine & 25 & 25 & 25 & 25 & 25 \\
Gluten & 10 & 10 & 10 & 10 & 10 \\
Vitamin \& Mineral & 2 & 2 & 2 & 2 & 2 \\
Oil & 3 & 3 & 3 & 3 & 3 \\
Baker Yeast & 0 & 2 & 4 & 0 & 0 \\
Tonilisite & 0 & 0 & 0 & 2 & 4 \\
\hline
\end{tabular}

Water quality analysis

Table 2 Chemical analysis of the selected experimental diets

\begin{tabular}{llllll}
\hline Item & G I & G2 & G3 & G4 & G5 \\
\hline Dry matter (DM) & 9.4 & 9.4 & 9.6 & 9.5 & 9.6 \\
Crude protein (CP) & 29.93 & 29.9 & 29.95 & 29.92 & 29.97 \\
Ether Extract (EE) & 6.52 & 6.57 & 6.6 & 6.58 & 6.61 \\
crude fiber (C F) & 4.37 & 4.32 & 4.3 & 4.27 & 4.25 \\
Ash & 8.37 & 8.32 & 8.29 & 8.25 & 8.22 \\
Nitrogen free extract(NFE) & 8.37 & 8.32 & 8.29 & 8.25 & 8.22 \\
\hline
\end{tabular}

Growth performance and survival rate

\section{Feed utilization}

Feed conversion ratio (FCR) was calculated according to the following equation: $\mathrm{FCR}=$ Feed intake $(\mathrm{g}) /$ Weight gain $(\mathrm{g})$.

\section{Histological Investigation}

At the end of the experiment, all fish were scarified. The liver and gonads were removed and weight to determine the hepatosomatic index $(\mathrm{HSI})^{15}$ and immediately Gonadosomatic index $(\mathrm{GSI})^{16}$ as follow: HSI = liver weight $\times 100$ /gutted fish weight GSI = gonads weight $\mathrm{x}$ 100/gutted fish weight

\section{3-8 Hematological and biochemical analyses:}

At the end of the experiment, blood samples were collected from the fish caudal peduncle of the different groups. Erythrocytes count (RBC's) and total leukocytes count (WBCs) were measured on an Ao Bright -Line Haemocytometer model (Neubauer improved, Precicolor HBG and Germany). Hemoglobin concentration ( $\mathrm{Hb}$ gm/dl) was estimated according to the method of Zinkl. ${ }^{17}$ Differential leukocyte count was estimated according to Vankamlen. ${ }^{18}$ A total protein (TP) concentration was measured according to the method of Henry. ${ }^{19}$ Alanine aminotransferase (ALT) and Aspartate aminotransferase (AST) activities were assayed according to the method of Reitman \& Frankel. ${ }^{20}$ Serum cholesterol $(\mathrm{mg} / \mathrm{dl})$ was estimated by enzymatic colorimetric methods. Triglyceride $(\mathrm{mg} / \mathrm{dl})$ was estimated according to the method of Fridewald et al. ${ }^{21}$

\section{Statistical analysis}

Data was subjected to one-way analysis of variance (ANOVA) followed by the Duncan's multiple comparison test for the means. The results are presented as mean $\pm \mathrm{SE}$ (standard diffusion) $(\mathrm{P} \leq 0.05)$. 


\section{Results}

\section{Chemical analysis of fish}

Yeast supplementation significantly $(\mathrm{P} \leq 0.05)$ affected wholefish body composition especially moisture with the yeast treatments at different doses. Fish fed on the control diet (G1) had the lowest protein content $(15.51 \pm 0.59)$. Yeast supplementation significantly $(\mathrm{P} \leq 0.05)$ improved the protein content and reach to $16.06 \pm 0.34$ in the catfish treated with $2 \%$ local yeast (G2). However, treatment with $4 \%$ local yeast and $2 \%$ or $4 \%$ imported yeast had a non significant change $(\mathrm{P}>0.05)$ in the protein content. No significant difference in lipid content (Ether Extract) in fish body was observed between the controlled (G1) and treated fish. Ash content had anon significant increase $(\mathrm{P}>0.05)$ in the fish in group $\mathrm{G} 2, \mathrm{G} 3, \mathrm{G} 4 \&$ G5 respectively. However, there is a significant increase $(\mathrm{P}>0.05)$ in ash content in the fish of group (G5) as shown in Table 3.

Table 3 Proximate chemical analysis of African catfish, Moisture (M), Crude Protein (CP), Ether Extract (EE), and Ash throughout the investigation period

\begin{tabular}{llllll}
\hline Group G I & G2 & G3 & G4 & G5 \\
\hline$M$ & $88.39 \pm 1.73$ & $72.50^{*} \pm 0.70$ & $72.5 I * \pm 0.69$ & $77.80 * \pm 0.30$ & $71.65^{*} \pm 0.18$ \\
$\mathrm{CP}$ & $15.5 \mathrm{I} \pm 0.59$ & $16.06^{*} \pm 0.34$ & $15.63 \pm 0.37$ & $15.51 \pm 0.29$ & $15.5 \mathrm{I} \pm 0.12$ \\
$\mathrm{EE}$ & $6.25 \pm 0.39$ & $6.19 \pm 0.17$ & $6.20 \pm 0.17$ & $6.34 \pm 0.39$ & $6.04 \pm 0.22$ \\
Ash & $5.74 \pm 0.34$ & $5.76 \pm 0.18$ & $5.82 \pm 0.13$ & $5.96 \pm 0.23$ & $6.32 * \pm 0.43$
\end{tabular}

*. Significant difference $(\mathrm{P} \leq 0.05)$

\section{Quality parameters of rearing water}

The present data showed that, during the experiment, there is a non significant change $(\mathrm{P}>0.05)$ in the ammonia, salinity, $\mathrm{pH}$ and temperature values in the catfish of groups G2, G3, G and G5, respectively comparing with the control group (G1) (Table 4).

Table 4 Means of water quality parameters, ammonia (NH3), salinity, hydrogen ion concentration $(\mathrm{pH})$ and temperature during the experimental period

\begin{tabular}{llllll}
\hline & GI & G2 & G3 & G4 & G5 \\
\hline NH3 g/l & $0.02+0.01$ & $0.03+0.01$ & $0.03+0.02$ & $0.03+0.01$ & $0.04+0.03$ \\
salinity & $0.22+0.02$ & $0.22+0.02$ & $0.20+0.00$ & $0.20+0.00$ & $0.23+0.04$ \\
Ph value & $8.56+0.08$ & $8.52+0.03$ & $8.28+0.11$ & $8.33+0.14$ & $8.25+0.21$ \\
Temperature & $27.18+0.49$ & $27.18+0.49$ & $27.18+0.49$ & $27.18+0.49$ & $27.18+0.49$
\end{tabular}

\section{Growth performance and survival rate}

The data present showed that, there is a significant increase $(p \leq 0.05)$ in the gain weight of the catfish of groups G2, G3, G4 andG5, respectively comparing with the control group (G1). In addition, there is a significant increase $(\mathrm{P} \leq 0.05)$ in the specific growth rate of the catfish treated with $2 \%$ local yeast (G2) comparing with the control group (G1). However, there is a non significant increase $(\mathrm{P} \leq 0.05))$ in the specific growth rate of the catfish treated with $4 \%$ local yeast (G3) or $2 \%$ and $4 \%$ imported yeast (G4 and G5) comparing with the control group (G1). The present data showed that there is a significant decrease $(\mathrm{P} \leq 0.05)$ in the feed conversion ratio of the catfish treated with $2 \%$ local yeast (G2) comparing with the control group (G1). However, there is a non-significant decrease $(\mathrm{P} \leq 0.05))$ in the feed conversion ratio of the catfish treated with $4 \%$ local yeast (G3) or $2 \%$ and 4\% imported yeast (G4 and G5) comparing with the control group (G1). Generally, the survival rate for the control and the treated groups was $100 \%$ (Table 5).
Table 5 Means+ standard errors of the growth performance of the African catfish (Clarias gariepinus) exposed to different dietary treatments

\begin{tabular}{|c|c|c|c|c|c|}
\hline & G I & G2 & G3 & G4 & G5 \\
\hline IW(g) & $102.92+3.45$ & $99.27+4.62$ & $104.98+0.47$ & $|03.54+1.5|$ & $103.00+2.69$ \\
\hline FW(g) & $|28.50+0.7|$ & $136.75^{*}+2.47$ & $141.10 *+1.27$ & $|39.00 *+1.4|$ & $|38.50 *+0.7|$ \\
\hline $\mathbf{G}(\mathrm{g})$ & $25.58+2.74$ & $37.49 *+2.14$ & $36.13^{*}+1.75$ & $35.47^{*+0.09}$ & $35.50 *+3.39$ \\
\hline$A D G(g)$ & $341.07+36.58$ & $499.80 *+28.57$ & $481.67 *+23.29$ & $472.87^{*+1.22}$ & $473.33^{*}+45.25$ \\
\hline G\% & $24.92+3.50$ & $37.86 *+3.92$ & $34.42 *+1.82$ & $34.26 *+0.59$ & $34.52^{*+4} .20$ \\
\hline SGR(\%/day) & $0.37+0.04$ & $0.54^{*}+0.05$ & $0.50+0.02$ & $0.50+0.01$ & $0.50+0.05$ \\
\hline FI & $160.51+2.23$ & $159.65+1.24$ & $|66.06+7.8|$ & $166.36+2.40$ & $167.97+5.19$ \\
\hline FCR & $5.72+0.69$ & $3.87^{*}+0.25$ & $4.18+0.40$ & $4.25+0.06$ & $4.32+0.54$ \\
\hline S\% & 100 & 100 & 100 & 100 & 100 \\
\hline
\end{tabular}

*- Significant differences $(p \leq 0.05)$

IW: Initial weight; FW: Final Weight; G: Gain; ADG: Average Dally Gain; SGR: Specific Growth Rate; FI: Feed Intake; FCR: Feed Conversion Ratio; SR: Survival Rate

\section{Histological investigation}

The present data showed that there is a significant increase $(\mathrm{P} \leq 0.05)$ in the Gonadosomatic index of the male catfish treated with $2 \%$ local yeast (G2) and $4 \%$ local yeast (G3) comparing with the control group (G1). However, there is a non significant decrease $(\mathrm{P}>0.05)$ in the Gonadosomatic index of the male catfish treated with or $2 \%$ imported yeast $(\mathrm{G} 4)$ and a non significant increase $(\mathrm{P}>0.05)$ in the Gonadosomatic index of the male catfish treated with $4 \%$ imported yeast (G5), respectively, comparing with the control group (G1). Furthermore, there is a significant increase $(\mathrm{P} \leq 0.05)$ in the Gonadosomatic index of the female catfish treated with $2 \%$ local yeast (G2), 4\% local yeast (G3) and 2\% imported yeast (G4), respectively, comparing with the control group (G1). However, there is a non significant increase $(\mathrm{P}>0.05)$ in the Gonadosomatic index of the female catfish treated with $4 \%$ import yeast (G5) comparing with the control group (G1). On the other hand, there is a non significant change $(\mathrm{P}>0.05)$ in the hepatosomatic index of all treated groups $(\mathrm{G} 2$, G3, G4, G5), respectively, comparing with the control group (G1) shown in Table 6.

Table 6 Means + Standard errors of the internal organs induce of the catfish at the end of the investigation period as affected by the different yeast levels

\begin{tabular}{llllll}
\hline & GI & G2 & G3 & G4 & G5 \\
\hline GSI (M) & $0.62+0.06$ & $\mathrm{I} .12^{*+0}+17$ & $\mathrm{I} .5 \mathrm{I} *+0.0 \mathrm{I}$ & $0.58+0.06$ & $0.95+0.03$ \\
$\mathbf{G S I}(\mathbf{F})$ & $2.34+0.06$ & $4.06 *+0.93$ & $3.85^{*+0}+07$ & $4.05^{*}+0.07$ & $2.70+0.28$ \\
HSI & $\mathrm{I} .15+0.07$ & $\mathrm{I} .08+0.1 \mathrm{I}$ & $\mathrm{I} .12+0.03$ & $\mathrm{I} .07+0.1 \mathrm{I}$ & $\mathrm{I} .15+0.2 \mathrm{I}$ \\
\hline
\end{tabular}

*- Significant differences ( $\mathrm{p} \leq 0.05)$.

\section{Hematological and biochemical analyses}

Hematological parameters: The present data showed that there is a significant increase $(\mathrm{P} \leq 0.05)$ in the red-blood-cells count (RBC's) of the catfish treated with $2 \%$ import yeast (G4) comparing with the control group (G1). However, there is a non-significant change $(\mathrm{P}>0.05))$ in the red-blood-cells count (RBC's) of the catfish treated with $2 \%(\mathrm{G} 2), 4 \%$ local yeast $(\mathrm{G} 3)$ and $4 \%$ imported yeast (G5) comparing with the control group (G1). However, there is a non significant change $(\mathrm{P}>0.05)$ in the white blood cells count (WBCs), hemoglobin levels, deferential leucocytes count in all treated groups (G2, G3, G4 and G5) respectively, comparing with the control group (G1) shown in Table 7.

Biochemical parameters: The present data showed that there is a significant increase $(\mathrm{P} \leq 0.05)$ in the total protein of the catfish treated 
with $4 \%$ local yeast (G3) and $2 \%$ import yeast (G4) comparing with the control group (G1). However, there is a non significant increase $(\mathrm{P} \leq 0.05))$ in the total protein of the catfish treated with $2 \%$ local yeast (G3) or $4 \%$ imported yeast (G5) comparing with the control group (G1).

The data showed that there is a significant increase $(\mathrm{P} \leq 0.05)$ in the aspartate aminotransferase (AST) of the catfish treated with $2 \%$ local yeast and $2 \%$ and $4 \%$ imported yeast (G2), (G4) and (G5), respectively, comparing with the control group (G1). However, there is a non significant increase $(\mathrm{P}>0.05)$ in the aspartate aminotransferase (AST) of the catfish treated with $4 \%$ local yeast (G3) comparing with the control group (G1). In addition, there is a significant decrease $(\mathrm{P} \leq 0.05)$ in the alanine aminotransferase (ALT) of all treated groups
(G2, G3, G4 and G5) receptively, comparing with the control group (G1).

The data showed that there is a significant decrease $(\mathrm{P} \leq 0.05)$ in the cholesterol level of the catfish treated with $2 \%$ local yeast, $2 \%$ and $4 \%$ import yeast(G2), (G4) and (G5) comparing with the control group (G1). However, there is a non-significant decrease $(\mathrm{P}>0.05)$ in the cholesterol level of the catfish treated with $4 \%$ local yeast (G3) comparing with the control group (G1). In addition, there is a significant increase $(\mathrm{P} \leq 0.05)$ in the triglyceride level of the catfish treated with $2 \%$ local yeast (G2) comparing with the control group (G1). However, there is a non significant change $(\mathrm{P}>0.05)$ in the triglyceride levels of the catfish treated with $4 \%$ local yeast and $2 \%$ and $4 \%$ import yeast (G3), (G4) and (G5), respectively, comparing with the control group (G1) (Table 8).

Table 7 Haematological parameters of catfish (Clarias gariepnus) at different of yeast levels

\begin{tabular}{|c|c|c|c|c|c|}
\hline Parameters & GI & G2 & G3 & G4 & G5 \\
\hline 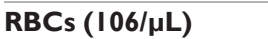 & $1.65 \pm 0.07$ & $1.60 \pm 0.00$ & $1.60 \pm 0.14$ & $1.85 * \pm 0.07$ & $1.65 \pm 0.07$ \\
\hline WBC cell ( $103 \backslash \mu L)$ & $25.00 \pm 1.4 \mid$ & $22.50 \pm 0.71$ & $22.50 \pm 2.12$ & $24.50 \pm 2.12$ & $25.50 \pm 0.71$ \\
\hline Hb (g|L) & $9.50 \pm 0.71$ & $1 \mathrm{I} .00 \pm 0.00$ & $9.50 \pm 2.12$ & $9.50 \pm 0.71$ & $\mid \mathrm{I} .50 \pm 0.7 \mathrm{I}$ \\
\hline \multicolumn{6}{|c|}{ Differential leucocytes count (\%) } \\
\hline Lymphocytes \% & $38.00 \pm 2.83$ & $36.50 \pm 0.71$ & $36.50 \pm 3.54$ & $37.50 \pm 0.71$ & $36.50 \pm 2.12$ \\
\hline Monocytes \% & $7.50 \pm 0.71$ & $7.50 \pm 2.12$ & $8.00 \pm 1.4 I$ & $7.00 \pm 0.00$ & $7.00 \pm 1.41$ \\
\hline Eosinophils \% & $2.50 \pm 0.7 \mathrm{I}$ & $3.50 \pm 0.7 \mathrm{I}$ & $3.00 \pm 0.00$ & $2.50 \pm 0.7 \mathrm{I}$ & $3.50 \pm 0.71$ \\
\hline Neutrophils \% & $51.25 \pm 2.47$ & $51.75 \pm 0.35$ & $51.75 \pm 5.30$ & $52.00 \pm 1.41$ & $52.25 \pm 3.89$ \\
\hline
\end{tabular}

Table 8 Physiological parameters of catfish (Clarias gariepnus) at different of yeast levels

\begin{tabular}{|c|c|c|c|c|c|}
\hline Parameters & G I & G2 & G3 & G4 & G5 \\
\hline Total proteins (g|L) & $14.80 \pm 0.14$ & $15.2 \pm 0.00$ & $15.4 * \pm 0.14$ & $201.00 * \pm 1.41$ & $15.1 \pm 0.14$ \\
\hline AST. (ulL) & $57.50 \pm 0.7 \mid$ & $61 * \pm 0.00$ & $60.00 \pm 1.41$ & $|9.50 * \pm 0.7|$ & $64^{*} \pm 0.00$ \\
\hline ALT. (ulL) & $22 \pm|.4|$ & $|8.00 * \pm 1.4|$ & $19.00 * \pm 1.41$ & $63^{*} \pm 1.41$ & $20 * \pm 0.00$ \\
\hline Chol. (g|L) & $217 \pm 2.83$ & $211 * \pm 1.41$ & $216 \pm 1.41$ & $201.00 * \pm 1.41$ & $|96.00 * \pm| .4 \mid$ \\
\hline Tri-G. (g|L) & $|8| .00 \pm 1.4 \mid$ & $|86 * \pm| .4 \mid$ & $182 \pm 0.00$ & $182 \pm 2.83$ & $181.00 \pm 0.00$ \\
\hline
\end{tabular}

\section{Discussion}

The present study showed that yeast supplementation improved the protein content in the catfish that treated with $2 \%$ local yeast. However no significant difference in lipid or ash content in both controlled fish body either the fish that treat with either local or import yeast. Abdel Tawwab et al. ${ }^{22}$ reported that changes in protein deposition and ash content in catfish body could be linked with changes in their synthesis, deposition rate in muscle and or different growth rate. The present data showed that the physico-chemical parameters of water throughout the experiment were within the acceptable ranges recommended for the culture of African catfish, $C$. gariepinus with regard to the ammonia, salinity, $\mathrm{pH}$ and temperature values. This is in consistent with Abdelhamid ${ }^{23}$ who recorded that the physico-chemical parameters of water were within the acceptable ranges recommended for pisciculture especially the culture of African catfish, C. gariepinus were aquaculture Research, Abbassa, AboHammad, Sharqia, Egypt. On the same side, Salem ${ }^{24}$ and Abdelhamid et $\mathrm{al}^{25}$ found that the best physico-chemical parameters of water for Nile tilapia were atmospheric temperature ranged from $23.5^{\circ} \mathrm{C}$ to $27.8^{\circ} \mathrm{C}$, salinity was between $0.2 \%$ to $0.3 \%$ and hydrogen ion concentration $(\mathrm{pH})$ was 8.2 to 8.63 .

The present study showed that there is a significant increase in the body weight and the specific growth rate the catfish that treated with $2 \%$ local yeast. However there is a significant decrease in the feed conversion ratio of the catfish that treated with $2 \%$ local yeast. The present study confirmed the previous findings showing the positive effect of yeast on growth rate, feed conversion ratio and nutrient efficiency utilization of catfish. ${ }^{26}$ Rumsey et al. ${ }^{27}$ explained that the enhanced growth performance and feed utilization may be due to the live yeast act as a source of some enzymes, amylase, protease and lipase which may improve food digestion and consequently food utilization. Lara-Flores et al. ${ }^{28}$ stated that the improvement of nutrient utilization and feed conversion ratio by using probiotic baker's yeast in African catfish diets may attributed to the act of the cell walls of yeast which provide very important non-nutritive compounds that may benefit fish health, including mannose. They added that the addition of live yeast improved diet and protein digestibility, which may explain the better growth and feed efficiency with yeast supplements. Therefore, from the previous results, it can be concluded that supplementation of a diet with a supplementation of a percentage of $2 \%$ of commercial local yeast probiotic could be beneficial for growth and survival of African catfish, especially in fast growing conditions, where it may be essential to stimulate the precocious of digestive system.

A significant increase in the Gonadosomatic index GSI. The stages of gonadal development observed in both male and female Pomadasys stridens in this study are according to Nikolsky. ${ }^{29}$ However, Abd ElHakim and El-Gamal ${ }^{30}$ found that the lead acetate is associated with the decrease in both of Gonadosomatic index and health state of Oreochromis niloticus. Moreover, Hussein and Kobeisy ${ }^{31}$ reported that HSI of the fish, Oreochromis niloticus was not affected by oxygen deficiency. A significant increase in the Red-blood-cells count 
(RBC's) of the catfish treated with 2\% import yeast was observed. This result agrees with Taoka et al. ${ }^{32}$ who investigated the effect of live and dead probiotic cells on the non-specific immune system of Nile tilapia. Fish hematology is gaining great attention in fish culture because of its importance in monitoring the health status of fish $^{33}$ Bakers' yeast is a source of nucleic acids and $\beta-1,3$-glucans which have been recognized to effectively enhance immune functions of African catfish. ${ }^{34}$

Moreover, a significant increase in the total protein of the catfish that treated with $4 \%$ local yeast or $2 \%$ imported yeast is observed. Plasma proteins were quantified according to Bradford ${ }^{35}$ with Comassie Brilliant Blue G-250 (Sigma) and using Bovine Serum Albumin (BSA) standards. In case of cultured species, occasionally health issues arise that necessitate clinical evaluation of the fish under such captive conditions. Lack of published species-specific normal reference ranges remains the primary reason that blood testing is not routinely performed in fish health evaluations. ${ }^{36}$ The hematological characteristic is an important tool that can be used as an effective and sensitive index to monitor physiological and pathological changes in fish. ${ }^{37}$

The data showed that there is a significant increase in the aspartate aminotransferase (AST) of the catfish treated with $2 \%$ local yeast and $2 \%$ and $4 \%$ imported yeast. In addition, there was a significant decrease in the alanine aminotransferase (ALT) of all treated yeast. AST and ALT belong to the plasma non-functional enzymes which are normally localized within the cells of liver, heart, gills, kidneys, muscle and other organs Carrillo et al. ${ }^{38} \mathrm{~A}$ significant in the cholesterol level of the catfish treated with $2 \%$ local yeast, $2 \%$ and $4 \%$ import yeast. In addition, there was a significant in the triglyceride level of the catfish treated with $2 \%$ local yeast comparing with the control group. Cholesterol is the most important sterol occurring in plasma, but in adrenal cortex, it occurs in esterifies form. ${ }^{39}$

\section{Recommendation}

The present study indicates that live yeast (Saccharomyces cerevisiae) positively enhance on feed utilization of catfish. However, no differed was found among local and imported live yeast, or among $2 \%$ and $4 \%$ supplementation levels. It's clear that use local baker's yeast at low levels preference in catfish feeds from economic view.

\section{Acknowledgments}

None.

\section{Conflicts of interest}

None.

\section{References}

1. Melloul A, Collin M. Key natural and anthropogenic parameters enhancing the effect of sea level rise: The case of Israel's Mediterranean coast. Ocean \& Coastal Management. 2009;52(1):39-46.

2. Field CB, Mortsch LD, Brklacich M, et al. North America. In: Parry ML et al. (Eds), Climate Change 2007: Impacts, Adaptation and Vulnerability. Contribution of Working Group II to the Fourth Assessment Report of the Intergovernmental Panel on Climate Change. Cambridge University Press, Cambridge, UK. 2007;pp.617-652.

3. CCSP. Coastal Sensitivity to Sea-Level Rise: A Focus on the MidAtlantic Region A report by the U.S. Climate Change Science Program and the Subcommittee on Global Change Research. US Environmental Protection Agency, Washington, DC, USA. 2009.
4. Karl TR, Melillo JM, Peterson TC. Global climate change impacts in the United States. Cambridge: Cambridge University Press. 2009

5. IPCC. Climate Change 2007: impacts, adaptation and vulnerability. Contribution of working group II to the fourth assessment report of the intergovernmental panel on climate change. Cambridge University Press, Cambridge, UK. 2007;pp.976.

6. Church JA, White NJ. A $20^{\text {th }}$ century acceleration in global sea level rise. Geophysical Research Letters. 2006;33(1):1-4

7. Lambeck K, Anzidei M, Antonioli F, et al. Sea level in Roman time in the Central Mediterranean and implications for recent change. Earth and Planetary Science Letters. 2004;224:563-575.

8. Nicholls RJ Small C. Improved estimates of coastal population exposure to hazards released. EOS Transactions. 2002;83(28):303-305.

9. IOC/UNESCO, IMO, FAO, UNDP. A Blueprint for Ocean and Coastal Sustainability. IOC/UNESCO, Paris. 2011

10. Nicholls RJ, Tol RSJ. Impacts and responses to sea-level rise: A global analysis of the SRES scenarios over the twenty-first century, Philosophical Transactions of the Royal Society A. 2006;364:1073.

11. Marbaix P, Nicholls RJ. Accurately determining the risks of rising sea level, EOS Transactions. 2007;88(43):441-442.

12. Travers A, Elrick C, Kay R. Background Paper: Climate Change in Coastal Zones of the Mediterranean. Priority Actions Programme, Mediterranean Regional Activity Centre, Coastal Zone Management Pty Ltd, Claremont, Australia. 2010.

13. European Commission. Sustainability Report. Luxemburg: Office for Official Publications of the European Communities. 2009;pp.160.

14. Carillo A, Sannino G, Artale V, et al. Steric sea level rise over the Mediterranean Sea: present climate and scenario simulations. Climate Dynamics. 2012;39(9/10):2167-2184.

15. Tsimplis MN, Marcos M, Colin J, et al. Sea level variability in the Mediterranean Sea during the 1990s on the basis of two 2D and one 3d model. Journal of Marine Systems. 2009;78(1):109-123.

16. Tsimplis MN, Baker TF. Sea level drop in the Mediterranean Sea: An indicator of deepwater salinity and temperature changes? Geophysical Research Letters. 2000;27(12):1731-1734.

17. Paulopoulos K, Chalkias C, Karimbalis E. Potential impact of sea level rise on Mykonos, Delos, Rinia islands, In: 6th Pan-Hellenic Geographical Conference, Thessaloniki. 2002;pp.3:469-476.

18. EUROSTAT. Coastal regions. In: Asa Onnerfors (Ed.), Eurostat regional yearbook 2011. Luxembourg: Publications Office of the European Union, Belgium. 2011

19. Coudert E, Larid M. IMAGINE: un ensemble de méthodes et d'outils pour contribuer à la gestion intégrée des zones côtières en Méditerranée, Vertigo-la revue électronique en sciences de l'environnement, Dossier : Les littoraux et la gestion intégrée des zones côtières. 2006;7(3).

20. Devoy RJN. Coastal Vulnerability and the Implications of Sea-Level Rise for Ireland. Journal of Coastal Research. 2008;24(2):325-341

21. Barth MC, Titus JG. Greenhouse effect and sea level rise: A challenge for this generation, Van Nostrand Reinhold, New York, USA. 1984;pp.324.

22. Milliman JD, Broadus JM, Gable F. Environmental and economic implications of rising sea level and subsiding deltas: The Nile and Bengal examples. Ambio. 1989;18(6):340-345.

23. Warrick RA, Barrow EM, Wigley TML. Climate and sea level change: Observations, projections, implications. Cambridge University Press, Cambridge. 1993

24. IPCC. Climate change 2001: impacts, adaptation and vulnerability. 
Contribution of the working group to the 3rd assessment report of the intergovernmental Panel on Climate Change. World Meteorological Organization, Geneva. 2001;pp.124.

25. IPCC. Climate change 2001: impacts, adaptations and vulnerability. In: McCarthy JJ, et al. (Eds.), Contribution of Working Group II to the Third Assessment Report of the Intergovernmental Panel on Climate Change. Cambridge University Press, Cambridge. 2001;p.75.

26. National statistical Survey of Greece. Population, housing and buildings Census 2001. 2003;p.18

27. Dubois RN. How does a barrier shoreface respond to a sea-level rise? Journal of Coastal Research. 2002;18:2.

28. Bruun P (1962) Sea-level rise as a cause of shore erosion. Journal of Waterways and Harbors Division: 117-130.

29. Rahmstorf S, Foster G, Cazenave A. Comparing climate projections to observations up to 2011. Environmental Research Letters. 2012;7:4.

30. Al-Buloshi A, Al-Hatrushi S, Charabi Y. GIS-based Framework for the
Simulation of the Impacts of Sea Level Rise and Coastal Flooding on Oman. Journal of Earth Science \& Climatic Change. 2014;5(10):1-6.

31. Neumann JE, Hudgens DE, Herter J, et al. Assessing Sea-Level Rise Impacts: A GIS-Based Framework and Application to Coastal New Jersey. Coastal Management. 2010;38(4):433-455.

32. Nicholls RJ, Tol RSJ, Vafeidis AT. Global estimates of the impact of a collapse of the West Antarctic ice sheet: an application of FUND. Climatic Changes. 2008;91(1-2):171-191.

33. Valiela I. Global coastal change. Wiley-Blackwell, London. 2006;pp.376.

34. Dasgupta S, Laplante B, Meisner C, et al. The impact of sea level rise on developing countries: a comparative analysis. Climatic Change. 2009;93(3-4):379-388.

35. Nicholls RJ. Coastal flooding and wetland loss in the $21^{\text {st }}$ century: changes under the SRES climate and socio-economic scenarios. Global Environmental Changes. 2004;14(1):69-86. 